\title{
Exploration on the Cultural Connotation of English and Chinese Numerical Digits
}

\author{
Yanling Chen \\ Department of English \\ School of Foreign Language \\ Heihe University \\ Heihe, China
}

\begin{abstract}
Initially, the numerical digits are the special symbols used to indicate quantity and size and to calculate. Different races of different countries and regions give special associative meaning to the numbers; as a result, the popular numbers have the characteristics beyond language, reflecting the different and colorful culture. Obvious cultural differences exist between Chinese and English numerical digits due to the differences in cultural psychology, way of thinking and religion. This paper intends to compare the numerical digits in different cultural contexts and to trace back the roots of cultural differences in the two kinds of numerical digits. The comparison of differences in Chinese and English numerical culture will help us to understand the numerical culture connotation of the two people, to reduce misunderstanding and conflicts in crosscultural communication and to ensure smooth progress of crosscultural exchanges.
\end{abstract}

Keywords-English and Chinese numerical digits; cultural connotation; cross - cultural communication; cultural differences

\section{INTRODUCTION}

In the long history of both China and western countries, numerical digits always run through people's lives. The continuous development of society also makes the relationship between numerical digits and people closer. The numerical digit itself does not have any mystery and commentary or derogatory meaning. But different meaning of Chinese and western numerical culture evolved out with the social development and the impact from factors such as religious beliefs, social customs, lifestyle, and aesthetic taste. It seems that numerical culture is insignificant, but it is always restricting people's behavior and relating to people's pleasure, anger and taboo.

Westerners are full of desire to explore the nature. People find that all things in the world have a close logical connection in the long process of cognition. Philolaus, a western philosopher believes that "numerical digit should not be regarded as a unit of measure, but as a region, which is dominant, permanent and fixed, linking everything internally." It can be seen that the Western people believe that numerical digit is the law for construction of all things and the language

Fund Project: Humanities \& Social Sciences research project of Education Department of Heilongjiang Province, "Study on Current Situation of Chinese Culture Education in Cross-cultural Foreign Language Teaching in Colleges and Universities" (12532232). of human to understand the nature and to communicate with God. The summary of western people's life experiences and experience determines their understanding of the numerical connotation.

Since the ancient times, many Chinese scholars have exploration on numerical digits. Ancient Chinese people believe that numerical digits can not only interpret all the things in the universe, but also can predict a man's fortune. The sermons come down from ancient times such as "天数已定 (meaning the fate has been set", "劫数难逃 (meaning the robbery cannot be avoided)," and make the connotation of Chinese numerical digits difficult to understand and mysterious. Therefore, it has become synonymous with astronomy, geography, ethics, customs and culture, and constitutes an indispensable part of Chinese traditional culture.

\section{ORIGIN OF CHINESE AND ENGLISH NUMERICAL DIGITS AND THE CULTURAL CONNOTATION DIFFERENCES}

Numerical digit is the combination of the concept and symbol summarized by the working people of their observation, exploration in combination with their own experiences. The unique numerical culture has been formed in the diversified national culture atmosphere and different language background. With influence of language semantics, religious beliefs, myths and legends, numerical digits are endowed with a mixed cultural connotation.

No matter in the modern or the ancient times, people of both east and west all worship numerical digits. Numerical digits are endowed with various mysterious meanings. In the ancient times, although people hardly understood language, they firmly believed language had a magic power that cannot be underestimated, and can bring blessing or disaster to people. "People's superstition and worship toward language is called language fetishism or language spiritual worship." People believe that language can bring about disaster to mankind. Those who respect it will be rewarded, and on the contrary, they will be subject to double punishment. Numerical worship also rises in response to the proper times and conditions. The spiritual worship toward numerical culture in Chinese and English culture endows numerical digits with mixed mysterious feature. 


\section{Cultural Connotation DifFerences IN Chinese AND ENGLISH NUMERICAL DIGITS}

\section{A. Preference and Taboo in Chinese and English Numerical Digits}

In Chinese traditional culture, "7" is regarded as one of the taboo numbers. People do not choose the date containing "7" day as an auspicious day. The reason is related to our country's custom of worshipping the departed ones. In our country, there is a saying goes that "avoid marring off daughter on the 7th day of the 7th lunar month, which is relevant to the legend of the Cowherd and the Weaving Maid. They can only meet on the 7th day of the 7th lunar month and their love is not perfect enough. Therefore, to have a marriage on this day means unlucky. As a result, when holding a wedding ceremony, people often regard "7" as a taboo. The idioms containing "7" are mostly derogatory, such as "七嘴八舌 (meaning all talking at once)", "七扭八歪 (meaning in a state of great disorder)" and so on.

In western countries, "7" is a symbol of "good fortune" and "happiness". In the ancient times of western countries, there was a saying that: "7" is the key to open the universe of all things. Westerners believe that Jehovah creates the world using six days, and that the seventh day is for rest. In the daily life, there are a lot of auspicious expressions relating to "seven", such as "lucky seven".

In the traditional Chinese culture, because the " 4 " is a homophonic word of "死(meaning die)", such as "74" is a homophonic word of "去死(meaning go to die)", "478" is a homophonic word of "死去吧(meaning to die)". Therefore, in China, people don't want to have a "4" in their license plate number, cell phone number, room number and so on.

The case is quite different in the western countries. They think that " 4 " is the same as a square, meaning "steadiness" and "perseverance". They also believe that "four" is a homophonic word of "fair", symbolizing fair, just and clever.

\section{B. Odd-Even Difference in Chinese and English Numerical Digits}

Respect for and worship toward the double things is the habit of Chinese people since ancient times. In the mind of Chinese people, even numerical digit is a symbol of good luck. Chinese traditional culture says that: "all things have Yin and Yang (two opposing principles in nature), only by combining Yin and Yang can the things be multiplied." Chinese people prefer double things and pursue double blessings. And they pursue symmetry in terms of literary forms. Moreover, the spring festival couplets also show Chinese people's special preference to even numbers.

Lao Tze hold the opinion that all things have two sides, namely mixed blessing, right and wrong, long and short, static and dynamic and so on, which is a good explanation and confirmation that Chinese people favored even numbers. For example, "6" is a favorite of Chinese people. "Six Way is also known as six directions, namely, front, rear, left, right, up, down, or four sides of the universe, or the six directions of three-dimensional space." (2) Therefore, "6" is called "harmony number of time and space." "6" is a homophonic word of “禄” in “福禄” (meaning happiness). “禄” means good fortune and also refers to the salary. “福禄安康(meaning happiness, salary and good health" expresses people's expectations. “六马仰秝(meaning horses listen to the music and forget to eat)”, “六畜兴旺(meaning domestic animals are all thriving) and “六六大顺 (meaning everything goes smoothly)", all these idioms have confirmed "6" is loved by the Chinese people deeply. People like to travel or to conduct a business activity on a day containing "6", as they believe they will earn good fortune if they invest in this day. People also like to choose the phone number or license plate number containing a "6", because it means auspicious and smooth.

Western people have attached importance to opposition since ancient times, emphasizing contradictions and individualities. All of these are originated from the cosmology of "separation of nature and human". They believe that everything in the world is opposed to each other and pursue the beauty of disharmony, which is manifested in the numerical culture vividly. Westerners think that even numbers are the embodiment of ominous and bad luck, and odd numbers symbolize lucky and good fortune (except 13). So they often send flowers of odd numbers. However, in China, this is a taboo, as items of odd numbers are used to pay homage to the deceased person.

\section{Difference in Ambiguous Meaning in Chinese and English Numbers}

Numbers are often the carrier of precise meaning, especially in science and technology. However, in the Chinese traditional culture, the number is often used in literary works to express ambiguous meaning, which is particularly prominent in the ancient poems. "The Song of Everlasting Sorrow" writes that “后宫佳丽三千人，三千宠爱在一身 (meaning there are thousands of beauties in the imperial harem, but the emperor only loves one of them)". The poem 《山村咏怀》 (singing in a village) by Shao Yongkang of Song Dynasty, gives full play to the ambiguous meaning of numerical digits. “一去二三里, 烟村四五家。亭台六七座, 八九十枝花 (meaning that it is about two or three miles away at first glance, four or five households are covered in the smoke. There are six or seven pavilions, and about ten flowers." The poem contains the numbers from one to ten, making people be immersed in the boundless imagination of rural scenery in the countryside. The numbers in this poem do not refer to the exact amount, but a vague concept, to convey the affection depicted in the poem to readers with the exaggerated or simple numbers.

When expressing imaginary meaning, ambiguous meaning of numbers will also be used in western countries. For example, "a hundred and one thanks/thanks a million" meaning "thank you so much", "one hundred and one other things" meaning "endless and many things". Another example, "trillions of" and "billions of" meaning a great many. The application of ambiguous meaning of numbers is often more refreshing than ordinary words.

It can be seen that in China, small numbers are often used to express the ambiguous meaning. But in the western 
countries, the large and exaggerated numbers are used to express fuzzy meaning.

\section{DIFFERENCE TRACING OF CHINESE AND ENGLISH NUMERICAL CULTURAL CONNOTATION}

\section{A. Different Phonetic and Semantic Systems of English and Chinese Nations}

English and Chinese have a totally different phonetic system, resulting in different homophones in Chinese and Western culture. English is a common immigrant language, belonging to the West Germanic languages under IndoEuropean language. However, Chinese belongs to the SinoTibetan languages.

The culture of representing a homophone or homophonic meaning by numbers is reflected profoundly in Chinese. For example, when selecting numbers, people usually choose "6" "8" and other auspicious numerical digits, but will not choose "4", this is because "6" is a homophonic word of "禄 $(\mathrm{Lu})$ " with the meaning of “福禄(good fortune)"; "8" is a homonym of “发( Fa)” with the meaning of “发财 (make a fortune”; and "4" is a homophonic word of “死( $\mathrm{Si})$ " meaning die, which is a taboo.

In the eyes of westerners, "six" is an ominous number, as it is a homophone of the devil "Satan" in the Bible, so people regard " 6 " as the number of beasts, and the idioms relating to "six" also have no good meaning. For example, hit sb. for six / knock sb. six (meaning to make someone a complete failure, or cause a heavy blow).

\section{B. Different Religious Origins of English and Chinese People}

Chinese people believe in Taoism, Buddhism, etc. since ancient times, and the preference of westerners toward number culture is mostly originated from the ancient Greek mythology and Christianity.

For example, the taboo on "13" by the westerners is originated from Christianity. According to the Bible, Jesus was crucified on the thirteenth day, and Adam also fell into temptation to eat the forbidden fruit on the thirteenth day. As a result, "13" has become a taboo of westerners, so they try to avoid "13". People replace No. 13 building and No. 13 doorplate with " $12 \mathrm{~A}$ ". There is No. 13 or Row 13 in the theater. However, Chinese people are willing to accept "13". Northern opera and folk songs are designated as "thirteen rhyme"; Confucianism contains 13 classic works, collectively referred to as "thirteen classics".

\section{Different Cultural Psychology of English and Chinese People}

China's traditional culture runs thousands of years and inherits the Confucian scholars' "ethical and moral" ideas and the view of "harmony between man and nature" of Taoism. The British and American culture is affected by the Christian doctrine of "Bible". China's society itself is a society attaching importance to ethical culture, paying attention to the harmony among human, nature and society. On the contrary, western people respect the opposition, advocate freedom and personality development.

\section{Different Myths and Legends of English and Chinese People}

The figures in myths and legends have a very close relationship with the inner meaning of numbers.

Nezha has "three heads and six arms", rendering him supernatural powers, so he can look at six ways and listen to all directions. He stabbed Wang Bao to death at Jiepai Pass, killed Long Anji for punishing the evil and praising the good, fought with Gao Lanying and killed her in Mianchi City, and wiped out the seven monsters completely together with Yang Jian at Meishan Mountain. In the ancient myths and legends, Nezha is all-conquering and never lose a battle, and his brave and mighty image has been deeply rooted in people's mind. Thus, "3" has a meaning of brave and fierce, sacred and inviolable.

There is certain traceable cause for westerners' preference of "3". Western countries are mostly enlightened by the ancient Greek and Roman culture, which is developed to some extent later. In the Roman mythology, the trigeminal lightning rod grants the Lord God the supreme position. Trident is a necessary weapon for Poseidon, and more surprisingly, a dog with three heads at the same time is actually the embodiment of Hades. These three gods lead everything in the word with absolute authority. So the western proverb says "Number three is always fortunate."

\section{EVOLUTION OF CHINESE AND ENGLISH NUMERICAL CUltural CONNOTATION}

\section{A. New Connotation on Original Numbers}

For example, the number "38", initially it refers to the annual Women's Day on March 8, later it is used to refer to "38" rifle. But in Hong Kong and Taiwan, the combination of the two numbers is a curse. As a result, "38" becomes a noun from numeral. It especially refers to "women frivolous behavior and boldness."

"76" was once an ordinary combination of numbers in the United States. But in 1976, the United States Department of Labor issued a decree on securing fair employment for the disabled, so now "76" means "disabled" in the United States.

\section{B. Changes in Complimentary and Derogatory Sense of Numerical Digits}

The number "2" was originally an auspicious number in Chinese culture, there the idioms such as “成双作对(meaning in couples or in pairs)”, “名利双收(meaning gain both fame and wealth)" and so on. But with the development of society and the integration of language and culture, the number "2" has derogatory meaning in some words, such as “二道贩子” refers to "the merchants who make exorbitant profits by illegal trading of goods", “二愣子” refers to the "rude person". Now "2" has been given a new meaning, for example, if we say if we say “某人很二”, it means this person does not consider the order of priority and takes something for granted. 
In some other countries " 7 " is auspicious number, because China advocates duality, so the Chinese people initially don't like this number. But with the progress of social development, "7" has been given a new meaning. "7" and "起" are similar in pronunciation, having the meaning of "rise". At present, especially the businessmen favor the number "7", and they often choose the license plate number containing "7" as the mantissa.

"9" is a recognized auspicious number in both China and Britain. Because 9 is a homophonic word of “久 (long)" meaning long-lasting and eternal in the traditional Chinese culture, so lovers often send 99 roses to each other, indicating long-lasting love. In the eyes of westerners, "9" means "more" and "deep". However, "9" is a taboo in the music circle in western countries; this is because Beethoven passed away after having created the well-known nine symphonies. Since then, many well-known composers, such as Schubert and Williams, also passed away after having completed 9 symphonies. As a result, the number " 9 " is given a tragic feature.

\section{CONCLUSION}

As a special cultural language, numbers reflect the profound philosophical thought and religious concepts in Chinese and western culture. English and Chinese culture is conceived in different social customs and way of act; meanwhile, it nourishes unique numerical culture. Numerical culture is the product of values, cosmology and aesthetics in the history of human development.

This paper starts from the origin of numbers, summarizes the differences in numerical culture between China and western countries, and thus explores the reasons of differences in numerical culture in China and western countries from four aspects: pronunciation system, religious belief, cultural psychology as well as myths and legends.

The comparative analysis on numerical cultural differences in China and western countries is a multi-level and multi-angle comprehensive comparative study. English and Chinese numerical terms form a kind of numerical culture in the totally different social context and cultural atmosphere. In the crosscultural communication, the effective study of numerical cultural connotation, flexible and clever application of number language and more understanding toward both sides of communication, can gain mutual respect, reduce misunderstanding and conflict in cross-cultural communication, so as to achieve smooth communication.

\section{REFERENCES}

[1] Liu Xiaoping. Comparison and Translation of English and Chinese Numeral Idiom Culture [J]. Journal of Huangshan University, 2009, (1).

[2] Sun Xin'ai. Numerical Culture in Chinese [J]. Higher Education Exploration, 2011, (2)

[3] Yu Shuying. Exploration on Cultural Origins of Chinese and English Number Differences [J]. Journal of Huaihua University, 2009, (9).

[4] Zhang Jianhua, Li Ying. Analysis of Numerical Cultural Connotation in Chinese and Western Culture [J]. Contemporary Education Forum, 2006, (1)
[5] Zhang Yiling. Analysis of English and Chinese Numerical Cultural Connotations [J].College English, 2006, (2).

[6] Xu Yiliang. A Contrastive Study on Fuzzy Semantic Meaning in English and Chinese Numbers [J]. Modern Chinese (Language Research Version) 2007, (3). 